\title{
Også et kort liv er verdifullt
}

For en tid tilbake, i mai, mistet jeg en datter. Hun var dødfødt. Det er slikt som skjer, og vi må alle akseptere at livet ikke alltid tar en rett og enkel vei.

Vår datter hadde et navn. Hun het Veslemøy. Helst ville vi at Veslemøy skulle få leve, men slik ble det ikke. I dag har Veslemøy en liten grav. Vi er glad for at vi har graven å gå til, for den symboliserer at Veslemøy var et menneske og at hun alltid vil være en elsket og savnet datter og søster.

Egentlig skulle vår datter hete Liv. Det var navnet vi foreldre var blitt enige om dersom vi skulle få en datter til. Men på ultralyd i uke 18 fikk vi beskjed om at ikke alt så bra ut, det kunne være mye som var galt. Vi ble redde. Situasjonen var uvirkelig. Så mens jordmoren var ute i gangen (hun ville prøve å få tak i en lege, en lege vi ikke ville ha), fikk Liv nytt navn. Hun gikk fra å være et symbol på muligheter og livskraft til å bli et barn som måtte beskyttes - mot fellesskapet, mot storsamfunnet, mot fordommer, mot uvitenhet, mot kostnadseffektivitet. Vår datter fikk navnet Veslemøy. Navnet Veslemøy uttrykte at hun var en liten, sårbar jente som trengte foreldrene og resten av samfunnet ekstra mye.

Det finnes ulike meninger og ulike løsninger. Noen mener, ut fra en barmhjertighetstanke, at et barn som er alvorlig sykt, skal slippe å bli født. Noen mener at hensynet til foreldrene og familien må veie så tungt at samfunnet har plikt til å opplyse og ansvar for at de ikke skal være uvitende om denne kommende byrden. Det finne mange foreldre som av ulike grunner ikke vil eller orker å ha slike barn - barn som trenger mye ekstra. Noen tenker nok at det å få slike barn, er selvvalgt elendighet.

Jeg mener først og fremst at det finnes mye dobbeltkommunikasjon. Ikke hos foreldrene, men hos politikere og helsepersonell, de som sier så mye om mangfold og valgfrihet, men som samtidig gjør vedtak og lager tiltak som er kostnadseffektive og leder til minimumsomsorg og tvangsaktige situasjoner.

Vårt møte med helsevesenet var ikke godt - fra mistanken om avvik forelå til Veslemøy døde spontant i uke 28. Vi er ikke de eneste foreldrene i Norge som opplever slike situasjoner og, heldigvis for oss, var vår opplevelse av krenkelse og tankemessig døvhet fra helsepersonell bare småtteri i forhold til liknende situasjoner andre kan berette om.

Vi vil alltid være glade for at vi valgte å fullføre svangerskapet med Veslemøy. Vi fikk den gleden å oppleve hennes utvikling og vilje til å kjempe, vi kjente bevegelsene hennes - og hun ble født. Det var godt å se henne, holde kroppen hennes inntil seg og få små avtrykk av hender og føtter. Ikke minst var det godt å ta henne med hjem, stelle henne og legge henne i en kiste og gi søsknene en mulighet til å uttrykke og leve ut sin tilknytning til Veslemøy.

Jeg ønsker å kjempe for barn som Veslemøy. Det trengs en offentlig debatt med tydelige stemmer som sier at de svakeste er verdifulle og at intet menneske er en byrde. Et samfunns styrke avhenger av hvor godt det klarer å ta vare på dem som ikke er kostnadseffektive ved første øyekast. Det nytter ikke å komme med et strengt lovverk, det eneste som virker er god omsorg - for foreldrene, for barnet som blir født, for familien. Det trengs en holdningsendring generelt. Det er også viktig å sette grenser for staten. I disse situasjonene må vi faktisk beskytte foreldre og barn mot ivrige og fordomsfulle barneleger og gynekologer, som indirekte uttrykker at foreldrene ikke har definisjonsmakt. Legemakten, som direkte eller indirekte uttrykker at det å ta liv er en barmhjertig og omsorgsfull handling. Det spilles på foreldrenes skyldfølelse. Er foreldre som fullfører svangerskap der det er konstatert avvik egoister?

Noen mener at jeg ikke utviser toleranse og empati med dem som avslutter svangerskap. Jeg vil derfor presisere at jeg har stor forståelse for at mennesker velger abort. Det er lov å utøve nødverge, slik jeg ser det. Jeg tolererer imidlertid ikke at helsevesenet og andre offentlige omsorgsutøvere forhåndsdefinerer menneskeskjebner og utviser sviktende selvrefleksjon. Å gripe fatt i denne situasjonen er et politisk ansvar.

Noe positivt har skjedd - helseministeren har nå tatt initiativ til å utvikle retningslinjer for oppfølging overfor familier som ønsker å fullføre graviditeten og hjelpe barnet frem. En prosess med å utforme retningslinjer er et første skritt.

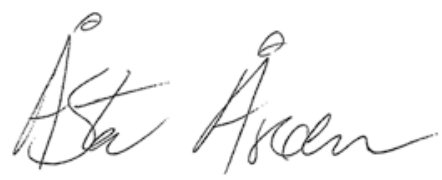

